\title{
Kiyoko CHIBA : Relation between the Mental and Physical Growth of Girls
}

Report 4. Concerning the Development of the Secondary Sexual Characteristics

\section{女巟の心身発達の相関に関する研究}

第 4 報 第二次性徴について

怙茶の水女子大学家政学部児童学科(指導 平井信義教授)

千 羽喜 代子

I 緒 言

思春期おるび青年期は内分泌的にみた Sutow 1)2）の分類ではまさに steroid 成長期に あたり，副腎皮質括よび生殖腺の steroid hormone が作用する時期である.

女児に沶いては estrogenの分泌增加にと もない卵栄, 子宮の発育に始まり, 乳房, 陰 毛, 成長の促進, 骨盤の拡がり, 腋窩毛, 初 経など，いわゆる第二次性徵の出現をみる。

脳下垂体の成長ホルモンと生殖ホルモンとの 関倸についての説明は未だ十分でなく，成長 に拉よぼす estrogenは androgen の乞れほ ど明らかに説明されていない，男・女性の性 原細胞が刺激をうけて成熟すると考学られれ る gonadotropin は，穴の分泌が亢進すれば 脳下垂体ホルモンの一つである成長 ホルモン の作用は減退してくるという3)。

このように身体の成長と性成熟とは密接な 関係があり，一般には身長の增加と性成熟と は捛抗的であると考えられているが，Hamblen ${ }^{4)}$ は脳下垂体の成長促進作用と性腺刺激作 用とは協力作用があると考光る。

脳下垂体前葉の全面的機能が早期に 発揮さ れると，早期成熟の生ずることは疑いのない ところであるが, 「Rpyor の初経 6 力月前の 間の身長，体重の増加は同年令で初経のない 少女の 6 力月間の值に比して身長, 体重とも
多く增加するすすなわち，性成熟過程に扔い て身長，体重の成長は顕著であるという調査 結果は, Hamblen の説を支持するであろう」 と説く者もある ${ }^{4)}$. しかし性成熟が停止すれ ば成長も停止するといわれる。

气れでは概して身体成長が性成熟に先がけ て生ずる現象をどのように理由ずければよい。 で山ろらか。渡辺 5 ) は初経と身体発育との関 係から脳下垂体の成長ホルモンが先きに動き， その後に性腺刺激ホルモンを分泌するもので あるとする、この両者の関係を明確にするこ とはかなり困難であろうと思うが，個人の成 熟過程に拈いて成長ホルモンの機能がや>先 行しながら協力的に作用し, 漸次生殖ホルモ ソの機能が旺盛となると仮定することは早計 であろうか．性成熟が早期に完成されるるの の成長の停止は早いかもしれないという推定 もされる。

身体に現われる第二次性徴は腰部のふくら， 久, 乳房の発育, 外陰発毛, 腋窩発毛の順に 現われるのが諸家の文献に見られるところで おる 2）3４４6).

初経発来は第二次性徵の完成期に初めて出 現するといら者もあるが2）3，幾つかの調查 結果からみると必ずしも第二次性徴の完成期 に出現するのではなく, 外陰発毛第 3 期 6), あるいは乳房第 3 期, 腋窩発毛開始期 7) 前後: 
等，第二次性徴の完成途上の各期に現われて いる。このように初経発来に関し内分泌上の 実験と実体調查との結果にくい違いの生じて いることは興味㟧る点である。また，腋毛は 初経に遅れて発毛し，第二次性徴としては最 も後期に現うれるようである7)。

第二次性徵々初経との関係についての本邦 女児の綎続研究はほとんどなく，すべて横断 研究にとどまっている．既初経者に乳房発達 のみられるむのと末だ認められないもののあ ること7) 9)，腋窝毛招よび外陰毛の見出され るるの，山るいは未だないものと，初経と乳 房，あるいは初経と腋盆毛との間の関係は一 定しない状態にあるといえる7）8）9。(しかも 一般に初経発来の早いものの第二次性徵はな 打完成の途上に出り，平均初経年令にあるる のの乞れは完成に近いというものもある4).

第二次性徵と身体発育との関係については 初経に関するものがほとんどで，乳房扔よび 体毛との関係につき調査したものは僅少であ る. 佐藤 7), 後藤 10), 栗岩 11), 辻 9) らはい ずれも乳房, 腋窝毛など第二次性徵の発達が 身体発育と有意なる 関係に㟧ることを認め, さらに荻野 12) は短厚型に較べると狭長型の方 が初経・乳房腋窩毛の 発現が早いといってい る。

初経に関しては門田 13)は骨年令の促進して いる者に初経の早いことを認め，また後藤 ${ }^{15)}$ は初経発来の早い地方は相対的に 体質指数が 高く，身長，体重いずれも大きく，自律神経 平衡得点も高い傾向にあることを認めている。 初経年令の早いものは遅いものに比し 身体発 育が優れ，初経発来直前の成長は初経発来後 の成長より大であり，初経発来と同時にその 後の成長は急に緩慢になっている5）14)。しか し初経の早いものの終末的身長は必ずしも良 好とはいえないとい〉，また，初経の遅い女 児で性初経前に身体発育促進をほとんどか， あるいは全く経験しないという16)。いずれに しても身体発育促進が初経の前後に生ずると
いい得るであろう。さらにこの関係を明確に しようとするためであろうが，初経発来は年 令よりも身長に関係があり，身長 $148 \mathrm{~cm}$ に

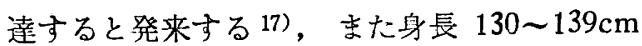
以上, 体重 $30 \sim 39.9 \mathrm{~kg}$ 以上になると乳房,

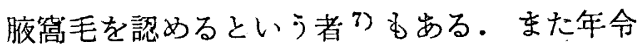
別身長，坐高別有経曲線により成熟度の判定 ならびに未経者に対する初経時期の 推定を試 みたもの18）もある。いずれも初経を成熟の尺 度とするための試みである。

以上の文献的考察により，われわれは初経 発来当時の個人の体型に何らかの特徵がない か，また初経発来の早発・遅発者の体型に相 異が出りわしないか、また, 最近初経発来が 年々早くなってきている事実があるが 19)，初 経の早発現象がみられれば当然气の他の第 二次性徵も早発していないかなどの実態を捉 え, さらに初経を予知して, 適切な指導を行 うために何らかの手眯りを得ることはできな いかを考兄，われわれの研究を進めた。本研 究に招いては, 初経時の体型, ならびに乳房, 腋窝毛状態について相関を求めた。この結果 について報告したい。

\section{II 研 究 方 法}

調査月日：初経調查, 昭和 32 年, 33 年, 34 年の 9 月

乳房, 腋窝毛観察, 昭和 34 年 4 月, 7 月, 11 月

対象：都内 $\mathrm{O}$ 附属小学校より高等学校まで の女児䄪 980 名

1) 初経時の体型の被験者は, 初経発来の 確定を被験者自身による想起法によったため， 下記のように選定した。すなわち岡田 20）も指 摘しているように想起法による誤差をまぬか れるため，3年間連続して同一人について記 録したもののうち，穴の゙゙れが前後 2 力月以 内にあるもののみ 391 名を対象とした。

口）乳房形態执よび大いさの分類は, 高等 学校 $1,2,3$ 年生女児の成熟乳. (第 5 期) にあ 
るもの 337 名につき行った。

八) 腋窩毛の観察に括いては中学 3 年生, 高等学校女性徒には実施不可能であった。

研究手続 :

a) 初経時の体型：初経発来時に最も近い 身長, 体重測定值をもって2 報 22) に抋いて報 告した 13 体型に基ずき個人の体型を描き集計 した。

b）乳房発達：乳房発達に関してはこれま では Stratzの分類を適用する者が多い５）7） 8）10１2）16２1)。 との他としては Zeller4), Reynolds 9) の分類がある.

本研究に括いては辻らの写真撮影9)を参照 し, Reynolds の分類によつた。すなわち， 乳房成熟段階

第 1 期（infantile form）乳頭だけがもち上 っているもの.

第 2 期 (budstage) 乳房扣よび乳頭が小さ い隆起として認められるもの.

第 3 期 (intermediate stage) 乳房拉よび乳 輪がもり上ってはいるが，これらの輪部がは つきり分けられていないるの。

第 4 期 (primary mamma stage) 乳輪拈よ び乳頭が乳房の上に第 2 の突出として認めら れるるの.

第 5 期 (maturestage) 乳輪が後退し乳房の 輪郭内にふくまれ，乳頭だけが突出している もの.

な和整理するにあたり 乳房発達左右不同の 場合は発達乳房の方を選んだ。

乳房形態に 関しては栗岩 11) の分類（漏斗 状，皿状，半球状，鐘状，下垂状）があるが， 本研究では辻らの分類を使用した。すなわち, $\mathrm{A}$ (扁平型), B (半球型), $\mathrm{C}$ (円錐型), D (懸垂型) の4 型である. 乳房の大きさについ ては a (小), b (中), c (大) の 3 段階に分 類した。

c) 腋窝毛：従来 Zeller の分類 4) は山る が，特に定った標準はなく佐藤 7，荻野 12), 山口8）らとすそれぞれ各自で定め，ほゔ 3 段
階に分類している．本研究では辻 9）らの使用 した分類によって観察した。すなわち，

第 1 期 (一)，両側とも経来毛の認められな いもの.

第 2 期（土），片側または両側経来毛の発生 の兆出り，発毛部位のや〉黒ずんで見觉るも の.

第 3 期 $(+)$, 経来毛の発毛初期のもの.

第 4 期 (H)，成人に近いもの.

な扮観察にあたっては，検診時あるいは胸 囲測定時を所有しすばやく二名の測計者をも って観察した。計測者による観察誤差を少く するために 4 月， 7 月の 2 回にわたる 全員の 観察を行って充分に発達段階を知り，11月の 観察值をもって結果の整理にあたった。

d）乳房抒よび腋窩毛発達の年次比較

大正 15 年に調査した武政 22) の結果, 昭和 12 年の佐藤 7$)$ の結果を適用し, 本調査結果と の比較を試みた。武政は Stratz の段階をるっ て質問紙法による調査，佐藤は Stratz の法に より被験者を全裸にして観察を执こなってい る。したがって武政のは参考の程度にとどめ 特に後者の結果に重点を括いて比較した。な お本調査に拈いては乳房発達 5 段階を用いた ため両者の尺度基準が異る．したがって比較 に山たっては本調査の乳房発達段階 3,4 期を まとめて Stratz の第四段階とし, Stratz の分 類にまとめた。

腋營毛の発達比較は昭和 12 年調査の佐藤 7) の結果と本調査とを比較した。な打比較にあ たり前者は 3 発達段階, 後者は 4 発達段階で あるため，本調査の 2,3 期をまとめ，佐藤の 2 期にあてた。

\section{III 結 果}

a) 初経時の体型：初経発来年令は10才 より16才にわたっている.個人の初経発来時 の体型を初経発来年令別に示したものが第 1 表である、総括的にみた場合，C 型を示する のが最も多く111/391 (28.4\%), 次位は D お 
第1表 初経時の体型（実数および百分率）

\begin{tabular}{|c|c|c|c|c|c|c|c|c|c|c|c|c|c|c|}
\hline & & $\begin{array}{l}33 \\
84\end{array}$ & & & & & & & & $\begin{array}{l}4 \\
1.0\end{array}$ & $\begin{array}{l}30 \\
76\end{array}$ & & $\begin{array}{l}19 \\
5.0 \\
\end{array}$ & $39 i$ \\
\hline $\begin{array}{l}76 \\
15 \\
15\end{array}$ & 1 & 0 & 0 & 0 & 4 & 0 & & 0 & & 0 & 5 & 0 & 0 & \\
\hline 15 & 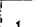 & & & & & & & & & & & & & \\
\hline 14 & 1 & 0 & 6 & 5 & $\because 15$ & 1 & 2 & 4 & 0 & 0 & 3 & 2 & 4 & 48 \\
\hline i3 & 3 & 9 & 19 & 30 & 14 & 1 & 6 & 7 & L & 3 & 7 & 0 & 8 & 1113 \\
\hline$\frac{1}{12}$ & 13 & 12 & 67 & & 15 & & 8 & 6 & 5 & 1 & 14 & 1 & 5 & 169 \\
\hline if & 4 & 10 & 111 & 4 & 1 & 11 & 1 & 2 & 1 & 0 & 1 & 0 & 2 & 46 \\
\hline io & 2 & 2 & & & & & & & & & & & & 4 \\
\hline$x_{4}$ & & $S_{B}$ & $\Omega_{c^{\prime}}$ & $\Omega$ & $\lambda_{E}$ & $\frac{S}{F}$ & $G$ & $y^{2}$ & 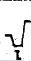 & & $k$ & 3 & L & it \\
\hline 10 & 6 & 12 & 19 & 4 & 1 & 1 & 1 & 2 & $t$ & 0 & 1 & 0 & 2 & 50 \\
\hline 12 & 120 & $2 \neq 0$ & 330 & 8.0 & 20 & 20 & 20 & 40 & 2.0 & 0.0 & 20 & 00 & 40 & \\
\hline 12 & 16 & 21 & 86 & 47 & 34 & 4 & 14 & 13 & 6 & 4 & 21 & 1 & 13 & 282 \\
\hline 14 & 5.7 & 7.5 & $i_{301}$ & 124 & 122 & 1.4 & 51 & 47 & 2.1 & 14 & 7.1 & 0.4 & 4.7 & \\
\hline$\frac{14}{3}$ & 2 & 0 & 5 & 5 & 119 & 1 & 3 & 9 & 0 & 0 & 8 & 2 & 4 & 59 \\
\hline 16 & 34 & 00 & 102 & 35 & 32.3 & 17 & 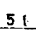 & 153 & 00 & 6 & 13 & 3.4 & 68 & \\
\hline $\begin{array}{l}10 \\
3 \\
13\end{array}$ & & 24 & 86 & 23 & 16 & 4 & 9 & 8 & 6 & 1 & 15 & 1 & 7 & 219 \\
\hline $\begin{array}{c}13 \\
4 \\
16\end{array}$ & & q & 25 & 35 & 38 & 2 & 9 & 16 & 1 & 3 & 15 & 2 & 12 & 172 \\
\hline${ }_{2}^{4}$ & & 5 & ฉุ & & $\pi$ & & & & & & & & & \\
\hline
\end{tabular}

よび $\mathrm{E}$ 型 60/391（約15\%)である.

次に初経の早発・遅発者の体型の比較を行 った。初経年令 13 才を境として,13才以前に初 経の発来したるのと13才以後に発来したもの に分㚈，カイ自乗执よび二項検定により有意 差検定を行った．有意差の認められたのは A， B， C, E，の4型である。この結果から13才 以前に初経の 発来した者は $\mathrm{A}, \mathrm{B}, \mathrm{C}$ 型に属 する者が多く，13才以後に初経発来した者に E 型に属する者が多い。

b) 乳房の発達：第 2 表は年令別による乳 房発達を示したものである. 小学 2 年生 $(6$ 才7ケ月〜7才6ケ月) では未だ乳房の発達を

第 2 表 年令別乳房の発達

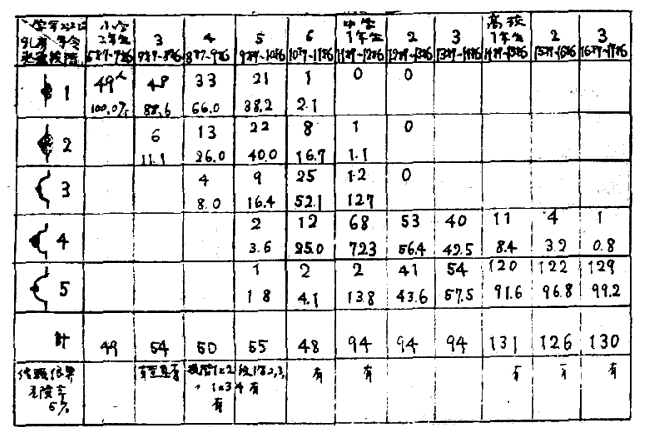

示するのは 1 例もない，しかし小学 3 年生 (7才 7 ケ月〜8才 6 ケ月) になると乳房発達 第 2 期を示すすのが約 $10 \%$ 程度現われてい る. 小学 4 年生 (8才 7 ケ月〜9才 6 ケ月) で は第 3 期を示するのが岁るが，過半数は第 1 期にとどまつている. 小学 5 年生（9才 7 ケ 月〜10才 6 ケ月) になると少数ではあるが第 4 , 第 5 期を現わするのがあり，第 1 期にある ものは約 $1 / 3$ とる. 小学 6 年生（10才7ケ月 〜11才 6 ケ月）では第 1 期に属するるのは注 とんどなく，過半数は第 3 期以上を呈する. 中学 1 年生（11才 7 ケ月〜12 才 6 ケ月）では 過半数が第 4 期を占め, 中学 2 年生 (12 才 7 ケ月〜 13 才 6 ケ月) になると殆んどの者が 4 ないし 5 期に属し, 中学 3 年生 (13才 7 ケ月 〜14才6ケ月) でも汪ざ同傾向を示しながら 第 5 期涂々に移行し，高校 1年生（14末7 ケ月〜15才6ケ月）からは急に第 5 期に属す るものが多くなっている. 高校 3 年生 (16才 7 ケ月〜17才 6 ケ月) では大部分が第 5 期に 達している。乳房発達は水学 5 年, 6 年, 中 学 1 年の 3 ケ年間敒 2 より第 4 期への 経過 が著しく行われることが認められる。

な抒，われわれの観察で值人の示す第 3 期の期間が比較的短いのではないかと思就 る.この事実は実際の観察場面での経験を通 し，山るいは第る表からす理解されるよらに 第 3 期にとどまる期間が小学 4 年生から 中学 1 年生の間であり，他にくらべるとその期間 の短いことがわかる.

c) 腋䆚毛の 発達：小学 4 年生（8才7ケ 月〜9才6ケ月) までは全々発毛を認めな为 った。 小学 5 年生 ( 9 才 7 ケ 10 才 6 ケ月) になって第 2 期を示するのが現わ就る。しか し大部分は未だ第 1 期にとどまっている。 小 学 6 年生（10才 7 ケ月〜11才6ケ月）では第 2 期を示すものが增し，第 3 期を示するの若 干山る、しかし過半数は第 1 期にある. 中学 1 年生（11才 7 ケ月～12才 6 ケ月）に至って 第 2 期を示するの半数を占し，第 3 , 第 4 期 
第 3 表 年命別腑简毛の発達

\begin{tabular}{|c|c|c|c|c|c|c|c|}
\hline 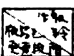 & 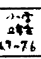 & $3^{3}-86$ & $\stackrel{4}{4}$ & $\begin{array}{c}5 \\
31-26\end{array}$ & . & 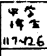 & ${ }_{12}^{2}+\sqrt{2}$ \\
\hline$=-1$ & $49^{4}$ & 54 & 50 & $\begin{array}{l}54 \\
8023 \%\end{array}$ & $\begin{array}{l}37 \\
756\end{array}$ & $\begin{array}{r}33 \\
359\end{array}$ & $\begin{array}{l}28 \\
30.1\end{array}$ \\
\hline ₹-2 & & & & $\begin{array}{c}1 \\
18\end{array}$ & $\begin{array}{c}10 \\
20.4 \\
\end{array}$ & $\begin{array}{l}42 \\
45.7 \\
\end{array}$ & $\begin{array}{r}39 \\
419 \\
\end{array}$ \\
\hline 7 & & & & & $\begin{array}{l}2 \\
4.1 \\
\end{array}$ & \begin{tabular}{|l|}
11 \\
12.0 \\
\end{tabular} & \begin{tabular}{|l|}
15 \\
16.1 \\
\end{tabular} \\
\hline$\approx i n 4$ & & & & & & \begin{tabular}{|l|}
6 \\
6.4 \\
\end{tabular} & \begin{tabular}{|c|}
11 \\
11.9 \\
\end{tabular} \\
\hline oा & 49 & 54 & 50 & 55 & 49 & 92 & 93 \\
\hline 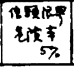 & & & & 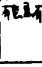 & 1 & 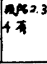 & 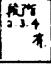 \\
\hline
\end{tabular}

に倠るものも多くなる。中学 2 年生 $(12$ 才 7 ケ月〜13才 6 ケ月) ではほら゙前学年と同じ状 態にある．その後の状態については測定不能 のため数值を出すことができなかった。

以上の 結果から腋窩毛の 発達第 1 より第 2 期へと著しく発達するのは中学 1 年生頃であ るといえよう。したがって腋窩毛の発達は乳 房発達に比較し約 2 年遅れていることがわか る。

d）乳房括よび腋窩毛発達の年次的比較

乳房の場合：昭和 2 年武政の調査，昭和12 年佐藤, 昭和 34 年本調査の結果を比較してみ よう。(第 1 図). 佐藤の結果と本調査の比較 を行うと, 乳房発達開始年令は小学 3 年生々 両者一致しているが，発現率は各期とも本調 査の方が高い。乙かも乳房発達の著しい年令 が本調查では小学 5 年生 9 才 7 ケ $~ 10$ 才 6 ケ月）より中学 1 年生（11才 7 ケ 月 12才 6 ケ月) であるが，佐藤の結果では小学 6 年 (11才) より高等女学校 2 年（13才）である. さらに infantile from 期完了は本調査 11 才, 佐藤の調査 12 才であり, mature stage を示 し始める者は本調査 10 才, 佐藤の調查 12 才 である。また本調查では高校 3 年生（16才 7 ケ月〜17才 6 ケ月) で大部分の者が乳房の成 熟をみるのに，一方では 17 才に拈いて未だ第 3 期にあるものが約 6\%岕る。したがって二 つの調査の比較から， その開始期には相異が みられないが，本調查の方が各期乳房の発達 は早く1〜2 年のずれがある。武政の大正 15
昭和 2 年(武政)，昭和 12 年(佐藤);昭 34 年 (本調査) の比校
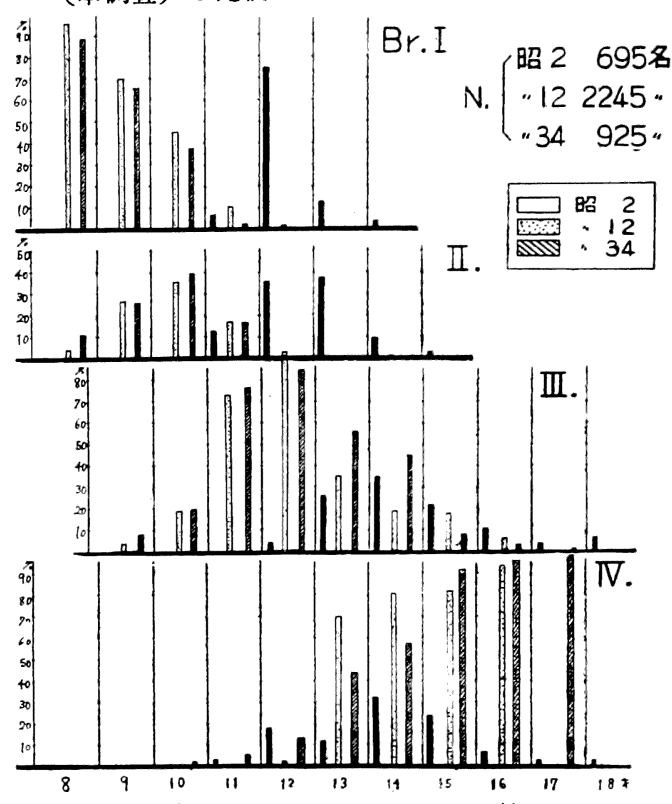

第 1 図 乳房発澾の年次的比較

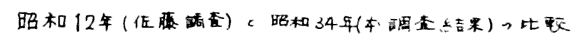

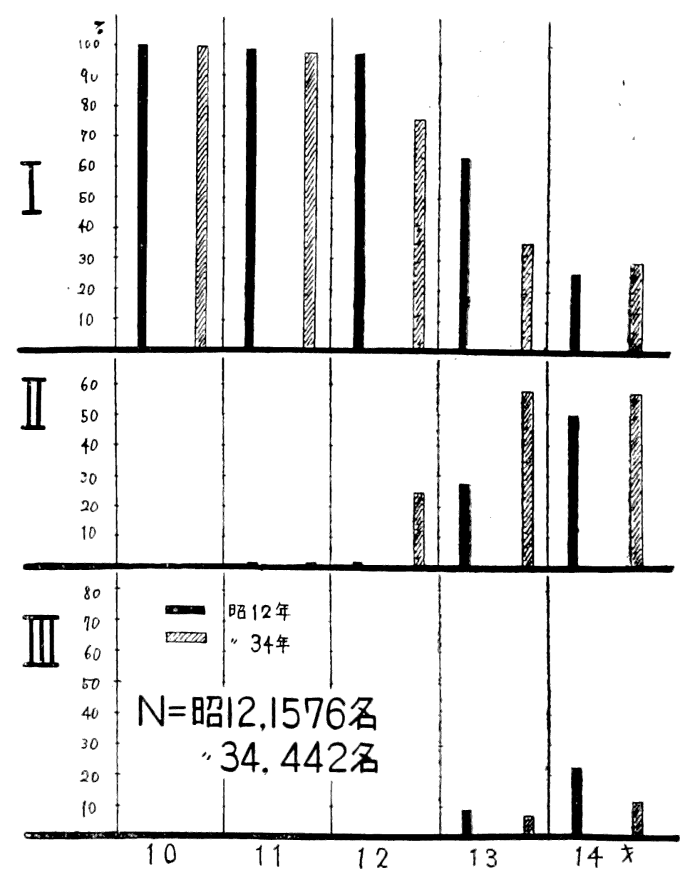

第 2 図腋管毛発達の年次的比較 
年の調查結果とでは第 2 期 13〜14 才, 第 3 期 12〜16才となり約 3 年のずれが生じている.

腋曧毛の場合：，同様に佐藤と本調査の比較 を行う(第 2 図). 腋窩毛の開始は小学 5 年生 (9才7ケ月〜10才6ヶ月) で, 発現率はほぼ 等しい. しかしその後の発達は本調查の方が 発達段階の発現率が高い。本調査では中学 1 年生（11才 7 ケ月〜12才 6 ケ月）頃に第 1 期 ～第 2 期へと藷しく発達するが，佐藤の結果 では高等女学校 2 年生 (13才頃) となってい る. その際の発達程度の年令別比較は本調査 の観察不能のため出来ない。腋窝毛の発毛開 始は同一年令であっても， 乞の発達過程に抹 いて本調査の方が $1 〜 2$ 年早くなっている.

e）乳房の形態括よび大きさ：第 5 期成熟 乳の形態抢よび大きさの 分類別実数は第 4 表 の通りである、形態は B (半球型) の者が過 半数をしめ, 大きさも中等度のものが多い。

第4表 成熟乳房の形応

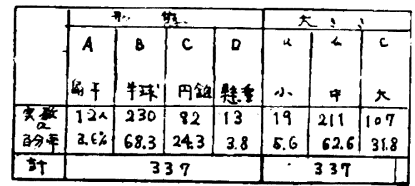

\section{VI総括および考察}

1）初経年令別体型の変化では C 型（年令 平均值に較べ身長大，体重は年令平均よりは 大であるが，身長汪どではない，充実した細 長型）をとるものが多い。この結果は, 先き に報告した第 2 報 20)の年令別体型の変化と同 じ結果を得たことになる。したがって，初経 時に打いては特定の体型をとると期待したの であるが，特にそのような偭向のないことを 知った.しかし C 型の示す曲線の勾配が顕著 である者が多く，身長も体重もともに充実し た頃であることを知る，特に次位の D 型（身 長は年令平均よりも高く，体重はほぼ年令平 均に等し）扣よび $\mathrm{E}$ 型（身長は年令平均より も高く，体重は年令平均以下) ‘り身長発達
が非常に盛んな時期であることがわかり，序 論に掠いて検討した文献と一致している。

2）初経発来の早発者乞遅発者との間に体 型の相異が出るか否かにつき，平均初経年令 13 才を基準にして早発・遅発の 2 集団に区分 して検討したところ, 早発者は $\mathrm{A}$ 型（身長， 体重ともに年令平均以上)， $\mathrm{B}$ 型（身長は年 令平均以上，体重は身長にうわまわって年令 平均以上), $\mathrm{C}$ 型に属する者多く, いずれる 身体発育は良好である。遅発者は E 型に属 する者が多く，身長の発育は良好であるが体 重の発育が悪く，非常に溲身の者である。上 坪 19) の結果では初経発来の早い者 C 型, 遅 い者 $\mathrm{K}$ 型となつており，初経遅発者の体型 はわれわれの結果と相異があるが，上坪の結 果は被験者数が少いため本研究の結果を認め てもよいと思う。

な招こ礼を事例的にみると特に初経発㷊の 早い者（10〜11才）4名はいずれすA ないし B 型に属している.15〜16才に初経発来した 遅発者 11 名のうち4名 $\mathrm{E}$ 型, 5 名 $\mathrm{K}$ 型 (身 長は年令平均以下，体重はさらに以下）とな り身体発育の不良を示している．残る2名の うち 1 名は $\mathrm{A}$ 型, 他の 1 名は $\mathrm{G}$ 型（身長, 体重りもに年令平均值）を示している：した がって初経早発者は身体発育の良好であると ほ济確定できるが，初経遅発者は必ずしもす べてが身体発育不良であるのではなく，多少 の例外のあることが認められる。

3) 乳房発達の早いものは 8 才でその発芽 を生ずる、17才では大部分が成熟の段階にあ る. 曾根 23) のレ線学的研究では乳房完成期は 17〜18 才頃であるとして括り，妊娠前の乳房 成熱完成は 18 才までに行われるとみてもよい であろう、乳最期より乳房期への移行は10才 より12才にかけて著しく行われることを知っ た。

4) 腋營毛の発毛は10才になって開始し, 乳房のそれに比べると2 年遅れており，すで に考察した諸調査 2)3）7）と一致する。 年の発 
盲の著しい時期は 12〜13 才頃である. 終局の 達は観察不能のため不明である.

な轮乳房ならびに 腋简毛の 各発達段階の平 可年令は本調査では未だ 年令別発達段階によ う分布状態を試べたにすぎないため今後各個 症例を追随観察し，個人の成熟完成期をま ，て算出する予定でいる。しかし乳房発達第 期 10 才，第 3 期 11 才，第 4 期 12 才，第 5 月 14 15才, 腋窩毛第 2 期 $12 \sim 13$ 才と概算 トることはできる。

5）乳房执よび腋䆚毛の発澾を昭和 12 年の ちれと比較したところ，その開始は一致して 、るが，弚の各期発達過程に括いてはいずれ , 本調査の方が早い, すなわち乳房発羍, 腋 舟毛発達いずれも 1〜2 年早くなっている。お ;特定の個人のみが早発・遅発するのではな ，一般に成熟が良好となっていることがわ ऽる.

6) 乳房発達 5 期成熟乳の形態括よび大き ミを分類したところ，形隼では半球型，大き らは中等度のるのが過半数を占めている．栗 刍11は5分類しているため彼の結果のうち皿 求と半球状の頻数を合せ, 本調査の結果と比 父するとほぶ 65\% と同率を示している。

7) 本調查では Reynolds の乳房発達 5 段 皆尺度を使用したのであるが，個人の発達過 靑を知るためにもう少し詳細な尺度を必要と トる．㑬人の乳房発達がほよ゙このような過程 経るのではおるまいか，公の過程を推定し 描いたのが第 1 図である.すなわち Reyno-

第 3 図乳房発達段階
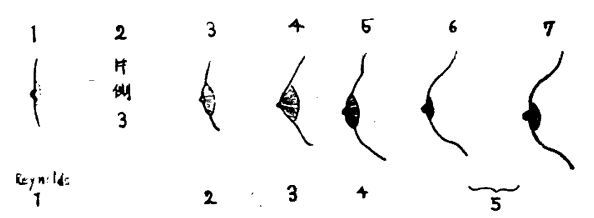

Is の分類第 1 期（乳頭だけがもち上つてい うもの）と第 2 期乳房怙よび乳頭が小さい隆 己として認められるもの) の間に, Wilkins ${ }^{24)}$
25）の示すように左右のどちらか一方が第 2 期 の状態にある時期がある。また第 5 期, (乳輪 が後退し乳房の輪部内にふくまれ，乳頭だけ が突出しているもの）の状態にあるが, 乳頭 も未だ小さく全体としてまだ末成熱であるも のと, 栗岩11)の示す完全乳頭をとる時期とが ある. したがって Reynolds の第 5 期には妊 婦乳前の成熟乳と乳頭の未完成な時期のある ことを知らなければならないと思う。

\section{$V$ 結 論}

第二次性徵の発達につき, 特に初経時の体 型, 乳房拉よび腋简毛の発達について調查し た。一般に初経時の体型は乞の一定時に特定 の型はとらないが，身体発育の最も盛んな時 であることを認めた。また初経早発者は身長， 体重いずれる年令平均以上の者多く身体発有 は良好であるが，遅発者は若干の例外は山る が，身長に対し体重の発育が悪くやせた者に 多い。

乳房拉よび腋営毛の開始は 8 才および 10 才 であり乳房発達は 17 才で一応完了する.また 両者ともに昭和 12 年と比較して開始期には相 異がないが，発達過程に拈いては一般に良好 になっていることを知った。

稿を䅂るにあたつて御指導を睗つた恩師平井 信義教授ならびに御校閲を睗った東邦医科大学 啮堀要教授に像心より感謝申し上げます。また 本調查に御協力をいたざいた本校校医本間達雄 先生, 星合, 金城, 山仲の諸先生, 钼察協力上 坪加代子氏，ならびに貴重な研究資料を御貸与 下さつた群馬大学计達㦄教授に厚く御礼申し上 げます。

\section{参 照 文 軒}

1) 小山良修: 小児生理学, 名取・中川編集, 韩 食㤹店，492 513，(1958）

2) Sutow. W.W: 青少年の成長発有飞関する内 分泌腺的因子について，ホルモンと蹈床,2(1): 8-23, (1954)

3) G. Fanconi und A. Wallgren: Lehrbuch 
der Pädiatrie, Benno Sghwabe \& Co, Verlag Basel Stuttgart : 292-296, (1956)

4) 古视：日本産婦人科全書, $32 / 3$, 金原出版: 303 336, (1958)

5) 渡匀克雄：初激と体格について，日本婦人科 学会雑誌, 38:522, (1943)

6) A.B. Nicolson. C. Hanley : Indices of $\mathrm{Ph}$ ysiological Maturity, Child Development 24 (1): 1-38, (1953)

7) 佐藤美実：女子第二次性微に関する研究，日 本婦人科雑誌，32(下)：1534-1548，(1937)

8) 山口・相浦：女子学勤者の主婦人科学的調查, 産科之婦人科，14：110-112，(1936)

9）辻，荻原他：健康優良児にみられる乳房発育 の個人差について，小児保健研究，18(1)：914, (1959)

10) 後藤与一：思春期発育に関する一調査, 大阪 学芸大学紀要, (3)：59-72, (1954)

11) 栗岩純：女子学生の乳房形態について, 予報, 第 1, 第 2 編, 信州医学雑誌, 4(1): 40-42, 6(2): 57-62, 6(6):12-17, (1955)

12）荻原彰久：青年期婦人の発育に関する体質形 態学的研究, 印族微生, 22:174-188, (1956)

13）門田顯治：思春期に於ける女子の成長発育と 初潮の関係, 広島医学, 4(4): 309, (1956)

14）長池博子：初激年命と身体発育とに関する研
究, 東京女子医科大学雑誌, 28(3):183, (1958)

15）後藤光正：動態的体質の地誌的研究，新潟医 学雑誌, 71(12):1232-1243, (1957)

16）中川一郎: 思青期の成長, 第 1 出版株式会社: 22-25, (1959)

17）宗像次雄：呪童及び生徒の身長発育に関する 研究, 民族蕧生, 23(2)：9，(1957)

18）錫村満：思春期女子の有経率上り見た初潮の 発来, 民族唡生，25(5)：598〜616，(1959）

19）上坪加代子：女児の心身発澾の相関に関する 研究, 第 3 翰, 民族政生.

20）岡田宙次：二次性徵に伴な5情動之性教育, 横浜教育研究所所報, 19:8, (1957)

21）千羽喜代子：女児の心身発達の相関に関寸る 研究, 第 2 疑, 民族德生:

22）武政太郎：本邦女子の性的成熟期に関する一 考察, 教育心理研究, 1(7): 1-22, (1926)

23) 曾根久: 乳房形態のレ線学的研究, 日本座科 婦人科学会雑誌，6(2) 臨時增刊：122, (1954)

24) Alexis Labhart: Klinik der Inneren Sekretion, Springer Verlag Berlin, Gottingen Heidelberg. : 39, (1957)

25) L. Wilkins: The Diagnosis and Treatment of Endocrine Disorders in Childhood and Adolescence, Charles C Thomas. Publisher Springfield Illinois. U.S.A.: 189. (1957) 
resistivity and with resistibility. It suggests that the group with medium resistivity exists as a process to the group with resistivity. Thus, the main part of the mechanism of resistivity forming can be explained by the salutation theory, but the adaptation theory can not be disregarded.

(From the Dept. of Hygiene, Nippon Medical School, Tokyo)

\section{Relation between the Mental and Physical Growth of Girls \\ Report 4. Concerning the Development of the Secondary Sexual Characteristics \\ By}

\section{Kiyoko CHIBA}

The purpose of this research is to study: (1) whether there are any special characteristics in bodily development which typify the menarche, (2) whether there are any differences in body type between girls who reach the menarche early and those who reach it late, and (3) whether, corresponding to the gradual acceleration of the age when the menarche occurs, there is a corresponding acceleration of the development of the mammary shape and axillary hair.

The sudjects of the study were 980 girls from an urban elementary, middle, and high school.

The mammary shape development scale follows Reynold's classification, and the axillary hair scale follows Tsuji's classification.

The results are as follows:

1) There are no special characteristics in bodily development which typify the menarche, but the menarche coincides with the period of greatest individual growth in height. This fact is corroborated by many writers.

2) Girls who reach the menarche early (accelerated girls) show an optimum correlation between height and weight during their growth (Types A, B, and C). By contrast, girls who reach the menarche late (retarded girls) tend to be tall and thin and to show a poor correlation between height and weight during their growth (Type E).

3) Accelerated girls reached the bud stage of mammary shape development at eight years of age. The change from an elevated areola to she first swelling of the mammary shape, and again to a small mound formation, occurs between ten and twelve years of age.

Nearly all the subjects reached a mature stage of mammary shape development at seventeen years of age.

4) The appearance of axillary hair in accelerated girls occurs at ten years of age, 
about two years later than the beginning of mammary shape development.

5) As compared with the results of a 1937 study concerning the beginning and the rate of development of mammary shape and axillary hair, the results of this study (1957) show: (i) similar conclusions as regards the beginning of mammary shape and axillary hair growth, but (ii) as regards the rate of development, there is an acceleration of one or two years.

(From the Department of Child Studies Faculty of Home Economics, Ochanomizu University, Tokyo)

A Constitutional-Anthropological Study of the Inhabitants of Takachiho District, Miyazaki Prefecture, Japan

By

\section{Koichi YamaDA}

The writer made a biometric investigation from the constitutional-anthropological point of view, measuring bodies, limbs, heads and faces, for the 515 adult inhabitants of Takachiho-machi, Usuki-gun, Miyazaki-ken, in January, 1957. The followings are the findings from the examination of the measures and indices and the comparative analysis with those of the inhabitants of other districts covering twenty-five items.

1. The average height of the inhabitants of Takachiho district is $159.74 \mathrm{~cm}$, which belongs to the "short" height group according to the Martin's classification and to the "short medium" height group for the Japanese adults.

2. The cephalic index is $82.41,61.1 \%$ of them belong to the brachycephalic type.

3. The zygomatic arch width-mandibular angle width index is 77.60. Over half of them belong to the medium type.

The synthetical comparison by the average type index showed that they had the closest tribal affinity to the inhabitants of Aira district, then Murayama basin region, Hida and Northern Shinshu districts, and Tsushima island followed it, and they had the slight affinity to Ainos in Hokkaido, and the inhabitants of Ecchu, Sagami and Hitachi districts and Koga mountanius region. The comparisons by the index correlogram and other methods also revealed the similar results.

(From the Department of Hygiene, Nippon Medical College, Tokyo) 